\title{
Co-infection and Disease Severity of Ohio Maize dwarf mosaic virus and Maize chlorotic dwarf virus Strains
}

Katia Morales, United States Department of Agriculture-Agricultural Research Service (USDA-ARS) Corn, Soybean, and Wheat Quality Research Unit, Ohio Agricultural Research and Development Center, Wooster, OH; Jose Luis Zambrano, Instituto Nacional Autónomo de Investigaciones Agropecuarias, INIAP, Programa Nacional de Maíz, Quito, Ecuador; and Ohio State University Department of Plant Pathology, Ohio Agricultural Research and Development Center, Wooster; and Lucy R. Stewart, USDA-ARS Corn, Soybean, and Wheat Quality Research Unit and Ohio State University Department of Plant Pathology, Ohio Agricultural Research and Development Center

\begin{abstract}
Morales, K., Zambrano, J. L., and Stewart, L. R. 2014. Co-infection and disease severity of Ohio Maize dwarf mosaic virus and Maize chlorotic dwarf virus strains. Plant Dis. 98:1661-1665.

Two major maize viruses have been reported in the United States: Maize dwarf mosaic virus (MDMV) and Maize chlorotic dwarf virus (MCDV). These viruses co-occur in regions where maize is grown, such that co-infections are likely. Co-infection of different strains of MCDV is also observed, and a synergistic enhancement of symptoms in co-infected plants was previously reported. Here, we examined the impact of co-infections of two strains of MCDV (MCDV-S and MCDV-M1, severe and mild, respectively), and co-infections of

experiments. Quantitative plant growth and development parameters were measured and virus accumulation was measured by reverse-transcriptase quantitative polymerase chain reaction. Virus symptoms were enhanced and plants showed no recovery over time in co-infections of MDMV-OH and MCDV-S but virus titers and quantitative growth parameters did not indicate synergy in co-infected plants. MCDV-M1 co-infections with either MDMV-OH or MCDV-S did not show symptom enhancement or evidence of synergism.
\end{abstract} MCDV and MDMV in the sweet corn hybrid 'Spirit' in greenhouse
Maize dwarf mosaic virus (MDMV) and Maize chlorotic dwarf virus (MCDV) are both common maize-infecting viruses in the United States (18). MDMV is an aphid-transmitted member of the genus Potyvirus, family Potyviridae, and was originally described and isolated in Southern Ohio $(13,33)$. In infected plants, it and related viruses in the sugarcane mosaic virus subgroup of the genus Potyvirus cause Maize dwarf mosaic disease $(18,33)$. MCDV, transmitted by the blackfaced leafhopper, Graminella nigrifrons, was also originally isolated in southern Ohio (27). MCDV is a member of the genus Waikavirus in the family Secoviridae (29). As the name indicates, it causes stunting and chlorosis in infected plants, with characteristic veinal chlorosis.

Both MDMV and MCDV were first described in the southeastern and Midwest corn-growing regions of the United States, emerging as a significant disease complex in the 1960s to 1970s $(8,9,13,20,27)$. Control measures have been successful in reducing the impact of disease in subsequent decades but both viruses are still present, and some varieties of cultivated sweet corn in the United States remain susceptible, at least to MDMV (40; unpublished data). Given the co-occurrence of the viruses, we examined whether they had potentially agriculturally significant interaction in co-infections. Despite the overlapping distribution of the viruses and some anecdotal reports of more severe disease pressure with both viruses, controlled studies testing disease

Corresponding author: L. R. Stewart, E-mail: lucy.stewart@ars.usda.gov

Mention of trade names or commercial products in this publication is solely for the purpose of providing specific information and does not imply recommendation or endorsement by the United States Department of Agriculture (USDA).

Accepted for publication 24 April 2014.

http://dx.doi.org/10.1094/PDIS-12-13-1230-RE

This article is in the public domain and not copyrightable. It may be freely reprinted with customary crediting of the source. The American Phytopathological Society, 2014. outcomes of co-infections have never been reported to our knowledge (8).

Virus co-infections are not unusual in cropping systems and in natural ecosystems. Several possible outcomes of virus co-infections have been described and reviewed elsewhere (26,36), and can be categorized as neutral (no interaction between co-infecting viruses), antagonistic, or synergistic. Antagonistic interactions include competition or superinfection exclusion of co-infecting viruses and can be an important agronomic outcome with utility for controlling virus diseases such as by cross-protection (36). Synergistic interactions, in which transmission or virulence of one or both viruses is increased in a more than additive manner in coinfections (41), are especially important to agriculture because they result in exacerbated disease. Synergy has been measured differently in different studies, usually using multiple parameters. A synergistic interaction may result in higher titers of one, both, or neither virus but, by definition, results in more than additive disease symptoms or enhanced transmission of at least one virus (41). Synergistic virus interactions cause several important viral diseases worldwide, including rice tungro disease $(10,11)$, maize lethal necrosis $(7,30)$, and sweet potato virus disease (15).

MDMV is prevalent in southern Ohio, and infection of maize with MDMV has also been shown to increase susceptibility to other nonviral diseases (22). A prior study indicated that co-infection of two different strains of MCDV, one mild and one severe, resulted in synergistic infection with very severe symptoms (6). The relative rarity of synergy resulting from co-infections of different strains or isolates of the same virus $(3,23)$, and findings that MCDV-M1 is prevalent in southern Ohio (L. R. Stewart, R. Teplier, J. C. Todd, M. W. Jones, B. J. Cassone, S. Wijeratne, A. Wijeratne, and M. G. Redinbaugh, in press, Phytopathology), as well as the absence of information about virus titer during coinfection, prompted our reexamination of interactions between coinfecting MCDV strains as well as MDMV/MCDV co-infection.

\section{Materials and Methods}

Treatments. MCDV-S/MDMV-OH, MCDV-M1/MDMV-OH, and MCDV-M1/MCDV-S co-infections were tested in three sepa- 
rate sets of experiments, each with four treatments: single infection of each virus, co-infection of two viruses, and healthy control. For MCDV-S/MDMV-OH co-infection experiments, 30 plants of sweet corn hybrid 'Spirit' were tested per treatment; whereas, for MCDVM1/MDMV-OH and MCDV-M1/MCDV-S co-infection experiments, 20 plants were tested per treatment. Each experiment set was repeated three times.

Virus isolates. MCDV-M1, MCDV-S, and MDMV-OH were used. Isolates were originally collected near Portsmouth, $\mathrm{OH}$ $(12,17)$ and complete sequences have been reported $(4,35$; R. E. Gingery, R. Chaouch-Hamada, M. G. Redinbaugh, and S. A. Hogenhout, unpublished).

Planting. Single seed were planted into 21-by-3.8-cm "Conetainers" (Stuewe and Sons Inc.) containing greenhouse soil (Potting Mix; Lawn Products Inc.) and one tablespoon of Scotts Osmocote Classic Controlled Release Fertilizer.

Inoculation with MCDV. Insects were used for inoculation with MCDV, using methods similar to those previously described $(19,37)$. Five days after planting, uniform seedlings were selected and distributed among four 30.5 -by-30.5-cm racks (Stuewe and Sons Inc.), each holding 49 seedlings. Then, 400 viruliferous $G$. nigrifrons were introduced to seedlings in two dacron cages for inoculation with MCDV-S or MCDV-M1. For postinoculation with MDMV-OH and healthy control, 400 nonviruliferous $G$. nigrifrons were introduced in two cages of plants. To maximize infection, insects were removed and a fresh batch of viruliferous insects was added every other day for a total of three inoculations. At day 11 post-planting, plants were fumigated and transferred to greenhouses for symptom development. MCDV-infected plants were selected by symptoms (MCDV-S) or reverse-transcriptase polymerase chain reaction (RT-PCR) (MCDV-M1). For MCDVM1/MCDV-S co-infection, three inoculations with 400 viruliferous leafhoppers were done for each virus.

Inoculation with MDMV-OH. Twelve-day-old plants were inoculated with MDMV-OH after leafhopper inoculations. MDMV$\mathrm{OH}$-infected maize leaves were ground 1:10 (wt/vol) in $0.01 \mathrm{M}$ potassium phosphate buffer, $\mathrm{pH} 7.0$, and inoculated to test plants with carborundum. Rub inoculation was performed three times every other day on all leaves of the plants, as previously described (14).

Symptom evaluation. Symptoms were evaluated after the final day of inoculation with MDMV. At this time, the MCDV/MDMV$\mathrm{OH}$ co-infected plants were 7 days post first inoculation with MDMV-OH and 14 days post first inoculation with MCDV. For simplicity, this time point will be referred to as T1. Symptoms were evaluated four times (T1, T2, T3, and T4) at 7-day intervals. Length of longest leaf (centimeters), length of youngest leaf (centimeters), height of highest node (centimeters), and fresh plant weight (pounds) were the quantitative growth properties measured; vein banding, chlorosis, and mosaic were the qualitative symptoms. The two uppermost leaves of individual plants were scored for each symptom using a three-point scale, where $0=$ no symptoms, $1=$ mild or limited symptoms, and $2=$ intense symptoms.

Primer design. Primer3 v. 0.4.0 (28) was used for primer design and MacVector v. 12.6 was used for multiple sequence alignments of published virus genome sequences. RT-quantitative (q)PCR primers were MCDV-S 4148f 5'-TTGGGTGTGTGCCATTCT CCC-3' $\mathrm{Tm} 57.9^{\circ} \mathrm{C}$ and MCDV-S 4275r 5'-TGCCGCAGGTTG ACTGTCTAAG- $3^{\prime} \mathrm{Tm} 59.4^{\circ} \mathrm{C}$, yielding a $127-\mathrm{bp}$ product; and MDMV-OH 4272f 5'-GGATGTTGACGTTGTTGTCG-3' Tm $54.3^{\circ} \mathrm{C}$ and MDMV-OH 4413r $5^{\prime}$-TGGTTTTGTCCTCCC AACTC- $3^{\prime} \mathrm{Tm} 55.0^{\circ} \mathrm{C}$, yielding a 171 -bp product. Normalization $18 \mathrm{~S}$ primers based on GenBank sequence U42796.1 were designed and provided by Dr. Bryan Cassone (Ohio State University): $18 \mathrm{~S}-\mathrm{f}$ $5^{\prime}$-GATTCCGGTCCTATTGTGTTG- ${ }^{\prime} \mathrm{Tm} 53.4^{\circ} \mathrm{C}$ and $18 \mathrm{~S}-\mathrm{r} 5^{\prime}$ TTTCGCAGTTGTTCGTCTTT-3' ${ }^{\prime}$ Tm $52.9^{\circ} \mathrm{C}$, yielding a 125 -bp product. Primers were tested for amplification of a single product of expected size from template cDNA and tested for cycle threshold $(\mathrm{Ct})$ values and primer efficiency. Standard curve amplifications were performed using RT-PCR products (amplified using Access RT-PCR System; Promega Corp.) cloned into pGEM$\mathrm{T}$ Easy Vector (Promega Corp.), and expected insertions were verified by sequencing and plasmid digestion with EcoRI HF enzyme (New England Biolabs). Plasmids were used for dilutions for standard curves to validate primer pairs for RT-qPCR. Reactions were performed in a CFX96 Touch Real-Time PCR Detection System, using Bio-Rad's EvaGreen Fast SSO supermix and Hard-Shell 96-Well 480 PCR Plates, using a cycle of $95^{\circ} \mathrm{C}$ for $30 \mathrm{~s}$; followed by $95^{\circ} \mathrm{C}$ for $3 \mathrm{~s}, 57^{\circ} \mathrm{C}$ for $5 \mathrm{~s}$, and plate read repeated 30 times. Melting curve analysis was performed at 65 to $95^{\circ} \mathrm{C}$, in increments of $0.5^{\circ} \mathrm{C}$ per $5 \mathrm{~s}$ followed by plate reading.

SYBR Green RT-qPCR. Total RNA was extracted from $-80^{\circ} \mathrm{C}$ frozen leaves using Direct-zol RNA MiniPrep kit (Zymo Research Corporation). RNA was treated with DNase I (Invitrogen) according to the manufacturer's instructions. Total RNA $(1.0 \mu \mathrm{g})$ was used for each cDNA synthesis reaction. cDNA was synthesized using iScript Reverse Transcription Supermix (Bio-Rad) using oligo(dT) and random primers. RT-qPCR was performed using EvaGreen Fast SSO supermix according to the manufacturer's instructions. Primers were used at $0.25 \mu \mathrm{M}$ concentrations with 1:10 diluted cDNA (absolute cDNA concentrations were not measured). Five samples per treatment per experiment were used to measure virus [RNA]. RT-qPCR reactions were performed with three pairs of primers and each sample was analyzed in duplicate. Fold changes were calculated using $\Delta \Delta \mathrm{Ct}$ values.

Data analysis. Calculations for analysis of variance (ANOVA), least significant difference (LSD), and Dunnett tests were performed using SAS (SAS Institute, Inc.). For RT-qPCR analyses, ANOVA and LSD tests were performed using PROC GLM. Samples in which virus was detected or not detected did not match the treatment set and samples in which the values were outside of the mean \pm two standard deviations of the sample set were discarded At least three biological replicates were used for RT-qPCR analyses per treatment and time point.

\section{Results}

MCDV-S/MDMV-OH co-infection. For MCDV-S/MDMV-OH co-infected plants, we observed no quantitative growth parameters that were significantly different from at least one of the single virus-infected plant sets, except for area under the disease progress curve (AUDPC). Infected treatments were different from healthy plants for all parameters except length of longest leaf, in which MDMV-OH-infected plants were not significantly different from healthy plants. There were significant differences in longest leaf length between experiments, which were carried out from summer to fall (data not shown). Mean wet weights of MCDV-S-infected plants $(1.7 \mathrm{lb}[0.77 \mathrm{~kg}])$ and co-infected plants $(1.5 \mathrm{lb}[0.68 \mathrm{~kg}])$ were significantly were significantly lower than that of MDMV$\mathrm{OH}$-infected plants $(3.0 \mathrm{lb}[1.4 \mathrm{~kg}])$, which was significantly lower than that of healthy plants $(4.0 \mathrm{lb}[1.8 \mathrm{~kg}])$ (Table 1). AUDPC from $\mathrm{T} 1$ to $\mathrm{T} 4$ was significantly higher for co-infected plants than either single infection set, reflecting persistence of strong symptoms in co-infections but not single infections after T2 (data not shown). Chlorosis, mosaic, and vein-banding symptoms were stronger in co-infected plants compared with single-infected plants at T3 and T4 (data not shown).

The amount of MCDV-S RNA detected by RT-qPCR in the coinfection treatment was always greater than the amount present in the single-infection treatment but the difference was only significant in the first experiment. The amount of MDMV-OH RNA detected was significantly higher in co-infected plants than singleinfected plants only in the third experiment (Table 2).

MCDV-M1/MDMV-OH co-infection. MCDV-M1/MDMV-OH co-infection and single infections had similar longest-leaf lengths and highest-node heights (Table 3), differing only from healthy plants. The youngest leaf height was not significantly different between any treatments (Table 3). The fresh weight was lowest in plants singly or co-infected with MCDV-M1 (Table 3). Chlorosis symptoms were limited, and virus symptoms decreased from $\mathrm{T} 1$ to T4 in both MDMV-OH and co-infected plants (data not shown). 
MCDV-M1 symptom AUDPC was indistinguishable from healthy plants, and co-infected plants had symptom AUDPC similar to that of MDMV-OH single-infected plants (Table 3). Virus levels were not measured by RT-qPCR for MCDV-M1/MDMV-OH co-infection experiments.

MCDV-M1/MCDV-S co-infection. There was no significant variation between MCDV-M1/MCDV-S co-infection experiments, and no significant differences between co-infected plants and MCDV-S-infected plants for longest leaf length, highest node height, or wet weight (Table 4). No significant differences between healthy and MCDV-M1 single-infected plants were observed for any measurement except wet weight (Table 4). Symptom AUDPC of co-infected plants was intermediate between each single infection set (Table 4). Typical vein-banding symptoms induced by MCDV-S alone were strongest at T2 and T3 but limited by $\mathrm{T} 4$ (data not shown). Although MCDV-M1 was asymptomatic in most plants at the time points scored, infection was confirmed in ran- domly selected plants by RT-PCR. Some co-infected plants showed very severe symptoms before $\mathrm{T} 1$, with strong twisting and tearing most notable. However, these symptoms subsided by $\mathrm{T} 1$ and later time points, and twist and tear was negligible at these time points and, therefore, omitted from analyses (Table 4; data not shown).

\section{Discussion}

Natural virus co-infections in plants are common, and can impact disease potential. Because two major U.S. maize viruses, MDMV and MCDV, overlap in distribution, we compared single and co-infections for disease symptoms and quantitative plant growth parameters. Co-infection of MCDV-S and MDMV-OH resulted in enhanced persistence of disease symptoms but not reduced growth over 4 weeks after co-infection. Measurements indicated that neither MCDV-S nor MDMV-OH titer consistently increased in co-infected plants. The mild strain of MCDV (MCDVM1) showed no interaction with MDMV-OH in co-infections and

Table 1. Maize growth and symptoms in Maize dwarf mosaic virus (MDMV)-OH, Maize chlorotic dwarf virus (MCDV)-S, and co-infected compared with healthy plants

\begin{tabular}{|c|c|c|c|c|c|c|c|c|c|c|}
\hline \multirow[b]{2}{*}{ Treatment $^{b}$} & \multicolumn{10}{|c|}{ Phenotype score ${ }^{a}$} \\
\hline & $\begin{array}{l}\text { Longest leaf } \\
(\mathrm{cm})\end{array}$ & LSD & $\begin{array}{c}\text { Youngest leaf } \\
\text { (cm) }\end{array}$ & LSD & $\begin{array}{l}\text { Node height } \\
\quad(\mathrm{cm})\end{array}$ & LSD & $\begin{array}{l}\text { Wet weight } \\
\text { (kg) }\end{array}$ & LSD & AUDPC & LSD \\
\hline $\mathrm{HC}$ & 91.7 & A & 69.9 & A & 60.4 & A & 1.8 & A & 0.0 & A \\
\hline MDMV-OH & 77.6 & $\mathrm{AB}$ & 58.5 & $\mathrm{BC}$ & 46.5 & $\mathrm{C}$ & 1.4 & $\mathrm{BC}$ & 80.5 & B \\
\hline MCDV-S & 62.1 & $\mathrm{BC}$ & 56 & $\mathrm{C}$ & 48.7 & $\mathrm{BC}$ & 0.77 & D & 72.3 & B \\
\hline $\mathrm{S}+\mathrm{OH}$ & 52.3 & $\mathrm{C}$ & 47.3 & DC & 42.4 & $\mathrm{C}$ & 0.68 & D & 156.3 & $\mathrm{C}$ \\
\hline Prob F Treat $^{\mathrm{c}}$ & 0.0049 & $\ldots$ & 0.0012 & $\ldots$ & 0.0138 & $\ldots$ & 0.0012 & $\ldots$ & $<0.0001$ & $\ldots$ \\
\hline Prob F Exp ${ }^{\mathrm{c}}$ & 0.0006 & $\ldots$ & 0.0039 & $\ldots$ & 0.0358 & $\ldots$ & 0.0113 & $\ldots$ & 0.9842 & $\ldots$ \\
\hline
\end{tabular}

${ }^{a}$ Except for area under the disease progress curve (AUDPC), data presented are the means of T4 measurements from three experiments with 30 plants each. Quantitative scores: length of longest leaf, length of youngest leaf, height of highest node, fresh plant weight (lb), and AUDPC from T0 to T4 were calculated from summed scores for chlorosis, vein-banding, and mosaic.

${ }^{\mathrm{b}} \mathrm{HC}=$ healthy control, $\mathrm{OH}=$ Ohio isolate, $\mathrm{S}=$ severe strain, and $\mathrm{S}+\mathrm{OH}=$ co-infected.

${ }^{\mathrm{c}}$ Probability value from analysis of variance for differences between treatments and experiments.

Table 2. Amount of viral RNA detected by reverse-transcriptase quantitative polymerase chain reaction in Maize dwarf mosaic virus (MDMV)-OH, Maize chlorotic dwarf virus (MCDV)-S, and co-infected plants compared with healthy control maize

\begin{tabular}{|c|c|c|c|c|c|c|c|c|c|c|c|c|}
\hline \multirow[b]{3}{*}{ Treatment $^{b}$} & \multicolumn{12}{|c|}{ Relative amount of virus ${ }^{a}$} \\
\hline & \multicolumn{4}{|c|}{ Experiment 1} & \multicolumn{4}{|c|}{ Experiment 2} & \multicolumn{4}{|c|}{ Experiment 3} \\
\hline & $\mathbf{S}$ & LSD & OH & LSD & $\mathbf{S}$ & LSD & OH & LSD & $\mathbf{S}$ & LSD & $\mathbf{O H}$ & LSD \\
\hline $\mathrm{HC}$ & 0.86 & $\mathrm{C}$ & 0.9 & B & 0.98 & B & 2 & B & 1 & B & 1 & $\mathrm{C}$ \\
\hline MDMV-OH & 1.05 & $\mathrm{C}$ & 1,097 & A & 1.28 & B & 20,139 & A & 2 & B & 20,835 & B \\
\hline MCDV-S & 128 & B & 1 & B & 318 & A & 2 & B & 1,199 & A & 1 & $\mathrm{C}$ \\
\hline $\mathrm{S}+\mathrm{OH}$ & 740 & A & 1,315 & A & 388 & A & 16,898 & A & 1,606 & A & 38,416 & A \\
\hline Prob $F$ Treat $^{c}$ & $<0.0001$ & $\ldots$ & $<0.0001$ & $\ldots$ & $<0.0001$ & $\ldots$ & $<0.0001$ & $\ldots$ & $<0.0001$ & $\ldots$ & $<0.0001$ & $\ldots$ \\
\hline Prob F Exp ${ }^{\mathrm{c}}$ & 0.7825 & $\ldots$ & 0.931 & $\ldots$ & 0.556 & $\ldots$ & 0.3421 & $\ldots$ & 0.2774 & $\ldots$ & 0.5326 & $\ldots$ \\
\hline
\end{tabular}

a Amount of virus relative to one healthy control sample calculated with $\Delta \Delta$ cycle threshold fold change. ANOVA was performed on fold changes. Three to five samples per experiment per treatment were tested. Columns: S and OH indicate amount of virus detected using MCDV-S and MDMV-OH primers, respectively. Treatments with the same letters for Fisher least square difference (LSD) do not statistically differ.

${ }^{\mathrm{b}} \mathrm{HC}=$ healthy control, $\mathrm{OH}=$ Ohio isolate, $\mathrm{S}=$ severe strain, and $\mathrm{S}+\mathrm{OH}=$ co-infected.

${ }^{\mathrm{c}}$ Probability value from analysis of variance for treatment and experiment.

Table 3. Maize growth in Maize dwarf mosaic virus (MDMV)-OH, Maize chlorotic dwarf virus (MCDV)-M1, and co-infected compared with healthy plants

\begin{tabular}{|c|c|c|c|c|c|c|c|c|c|c|}
\hline \multirow[b]{2}{*}{ Treatment $^{b}$} & \multicolumn{10}{|c|}{ Phenotype score ${ }^{a}$} \\
\hline & $\begin{array}{l}\text { Longest leaf } \\
(\mathrm{cm})\end{array}$ & LSD & $\begin{array}{c}\text { Youngest leaf } \\
(\mathrm{cm})\end{array}$ & LSD & $\begin{array}{l}\text { Node height } \\
\text { (cm) }\end{array}$ & LSD & $\begin{array}{l}\text { Wet weight } \\
\text { (kg) }\end{array}$ & LSD & AUDPC & LSD \\
\hline $\mathrm{HC}$ & 111.8 & A & 80.4 & A & 68 & A & 1.5 & A & 0.0 & A \\
\hline MDMV-OH & 98.2 & B & 75.2 & A & 57 & B & 1.1 & B & 67.0 & B \\
\hline MCDV-M1 & 95.2 & B & 60 & A & 48.2 & B & 1.0 & $\mathrm{BC}$ & 4.7 & A \\
\hline $\mathrm{M} 1+\mathrm{OH}$ & 92.3 & B & 68.6 & A & 52.2 & $\mathrm{~B}$ & 0.86 & $\mathrm{C}$ & 65.6 & $\mathrm{~B}$ \\
\hline Prob $F$ Treat $^{\mathrm{c}}$ & 0.0003 & $\ldots$ & 0.004 & $\ldots$ & $<0.0001$ & $\ldots$ & 0.0103 & $\ldots$ & $<0.0001$ & $\ldots$ \\
\hline Prob $F \operatorname{Exp}^{\mathrm{c}}$ & 0.012 & $\ldots$ & 0.2033 & $\ldots$ & 0.0106 & $\ldots$ & 0.002 & $\ldots$ & 0.3423 & $\ldots$ \\
\hline
\end{tabular}

${ }^{a}$ Except for area under the disease progress curve (AUDPC), data presented are the means of T4 measurements from three experiments with 20 plants each. Quantitative scores: length of longest leaf, length of youngest leaf, height of highest node, fresh plant weight, and AUDPC from T0 to T4 were calculated from summed scores for chlorosis, vein-banding, and mosaic.

${ }^{\mathrm{b}} \mathrm{HC}=$ healthy control, $\mathrm{OH}=$ Ohio isolate, $\mathrm{M} 1=$ mild strain, and $\mathrm{M} 1+\mathrm{OH}=$ co-infected .

${ }^{\mathrm{c}}$ Probability value from analysis of variance for differences between treatments and experiments. 
Table 4. Maize growth in Maize dwarf mosaic virus (MDMV)-M1, Maize chlorotic dwarf virus (MCDV)-S, and co-infected compared with healthy plants

\begin{tabular}{lcccccccc}
\hline & \multicolumn{7}{c}{ Phenotype score $^{\mathbf{a}}$} \\
\cline { 2 - 9 } Treatment $^{\mathbf{b}}$ & Longest leaf $(\mathbf{c m})$ & LSD & Node height $(\mathbf{c m})$ & LSD & Wet weight $(\mathbf{k g})^{\text {LSD }}$ & AUDPC & LSD \\
\hline HC & 115.6 & A & 38.9 & A & 1.8 & A & 0.0 \\
MCDV-M1 & 105 & A & 34.1 & AB & 1.4 & B & 0.0 & A \\
MCDV-S & 75 & B & 25.5 & C & 0.64 & C & 62.5 & C \\
S + M1 & 79.1 & B & 27.7 & BC & 0.59 & C & 39.7 & B \\
Prob F Treat & & 0.0006 & $\ldots$ & 0.0237 & $\ldots$ & $<0.0001$ & $\ldots$ & $<0.0001$ \\
Prob F Exp & 0.1853 & $\ldots$ & 0.7366 & $\ldots$ & 0.9114 & $\ldots$ & $\ldots .2795$ \\
\hline
\end{tabular}

${ }^{a}$ Except for area under the disease progress curve (AUDPC), data presented are the means of T4 measurements from three experiments with 20 plants each. Quantitative scores: length of longest leaf, length of youngest leaf, height of highest node, fresh plant weight, and AUDPC from T0 to T4 were calculated from summed scores for chlorosis, vein-banding, and mosaic.

${ }^{\mathrm{b}} \mathrm{HC}=$ healthy control, $\mathrm{M} 1=$ mild strain, $\mathrm{S}=$ severe strain, and $\mathrm{S}+\mathrm{M} 1=$ co-infected.

${ }^{\mathrm{c}}$ Probability value from analysis of variance for differences between treatments and experiments.

had no effect on symptom development or duration. Co-infection of two of the MCDV strains, MCDV-S and MCDV-M1, resulted in plant growth reduction similar to MCDV-S single infection and visible virus symptoms intermediate between $\mathrm{S}$ and $\mathrm{M} 1$.

Co-infection of MDMV-OH and MCDV-S might be considered mildly synergistic because of persistence of stronger symptoms, according to a limited definition of virus synergism in which coinfection symptoms are more severe than additive effects of each individual virus (41). However, other parameters did not support characterization of the co-infection as synergistic. In several reported cases of virus synergy, a potyvirus enhances accumulation of another virus (1,24-26,39). However, MDMV-OH did not enhance titer of MCDV-S, nor did MDMV-OH titer rise. Similarly, Scott et al (31) reported an absence of synergism when evaluating the effects of MCDV and MDMV in several F1 crosses between resistant and susceptible maize lines. However, they relied on natural MCDV infections and obtained relatively low infection rates (31 and 65\% infection), confounding results with missed infections.

We did observe significant differences between replicated experiments in MDMV-OH/MCDV-S co-infection experiments. Plants were grown in the same greenhouses but experiments were a month apart (August, September, and October for experiments 1, 2, and 3 , respectively); therefore, ambient light, day lengths, and temperatures were different. Temperature has been reported to affect MDMV titer over time (38), and other environmental factors may also be important.

Despite the previous report indicating synergy of co-infecting mild and severe MCDV (6), co-infection of MCDV-M1 and MCDV-S was not synergistic in our experiments. There are few reports of co-infection by closely related viruses causing synergy $(2,16)$. More often, cross-protection or superinfection exclusion are observed in co-infections of closely related viruses $(5,32)$. In the case of MCDV, strains MCDV-M1 and MCDV-S are considered the same species but their sequences are quite divergent, sharing only $57 \%$ nucleotide sequence identity and 59\% amino acid identity (34). We observed symptoms intermediate between the two viruses in co-infected plants, which might be explained by competitive interaction of the related viruses. Interestingly, however, wet weight in co-infected plants was as low as in MCDV-Sinfected plants, rather than intermediate. Some of the experimental differences between our study and the previous report could be important, such as use of different maize cultivars or scoring over different time periods. Because MCDV strains used in the prior report of synergy were not sequenced at the time $(4,21)$, we cannot exclude the possibility of sequence differences in the viruses used.

We examined disease and plant growth outcomes of co-infections of major U.S. maize viruses with overlapping distributions: MDMV and MCDV. Despite extensive studies of these U.S. maize viruses because of their historic disease impact, the interactions of viruses in co-infected plants had not been the subject of careful examination. Although we did not observe strong synergism in the MCDV-S/MDMV-OH co-infection, as is seen in disease complexes such as maize lethal necrosis (30), the persistence of stronger symptoms in co-infected plants may have important implications for disease in susceptible maize where these viruses overlap.

\section{Acknowledgments}

We thank K. Willie (USDA-ARS) for expert technical assistance and B. Cassone and F. Cisneros (Ohio State University) for helpful discussion. J. L. Zambrano thanks INIAP for the fellowship to support his Ph.D. program.

\section{Literature Cited}

1. Anandalakshmi, R., Pruss, G. J., Ge, X., Marathe, R., Mallory, A. C., Smith, T. H., and Vance, V. B. 1998. A viral suppressor of gene silencing in plants Proc. Natl. Acad. Sci. USA 95:13079-13084.

2. Bag, S., Mitter, N., Eid, S., and Pappu, H. R. 2012. Complementation between two tospoviruses facilitates the systemic movement of a plant virus silencing suppressor in an otherwise restrictive host. PLoS One 7. Online publication. doi:10.1371/journal.pone.0044803

3. Baltenberger, D. E., Ohm, H. W., and Foster, J. E. 1987. Reactions of oat, barley, and wheat to infection with barley yellow dwarf virus isolates. Crop Sci. 27:195-198.

4. Chaouch, R., Redinbaugh, M. G., Marrakchi, M., and Hogenhout, S. A 2004. Genomics of the severe isolate of Maize chlorotic dwarf virus. Plant Prot. Sci. 40:113-119.

5. Folimonova, S. Y. 2012. Superinfection exclusion is an active virus-controlled function that requires a specific viral protein. J. Virol. 86:5554-5561.

6. Gingery, R. E., and Nault, L. R. 1990. Severe maize chlorotic dwarf disease caused by double infection with mild virus-strains. Phytopathology 80:687691.

7. Goldberg, K. B., and Brakke, M. K. 1987. Concentration of maize chlorotic mottle virus increased in mixed infections with maize-dwarf mosaic-virus, strain-B. Phytopathology 77:162-167.

8. Gordon, D. T., Bradfute, O. E., Gingery, R. E., Knoke, J. K., and Nault, L. R. 1978. Maize virus disease complexes in the United States: Real and potential disease problems. In: 33rd Annu. Corn Sorghum Res. Conf. American Seed Trade Association, Washington, DC

9. Gordon, D. T., and Nault, L. R. 1977. Involvement of maize chlorotic dwarf virus and other agents in stunting diseases of Zea mays in the United States. Phytopathology 67:27-36.

10. Hibino, H. 1983. Transmission of two rice tungro-associated viruses and rice waika virus from doubly or singly infected source plants by leafhopper vectors. Plant Dis. 67:774-777.

11. Hibino, H., Saleh, N., and Roechan, M. 1979. Transmission of two kinds of rice tungro-associated viruses by insect vectors. Phytopathology 69:12661268 .

12. Hunt, R. E., Nault, L. R., and Gingery, R. E. 1988. Evidence for infectivity of maize chlorotic dwarf virus and for a helper component in its leafhopper transmission. Phytopathology 78:499-504.

13. Janson, B. F., and Ellett, C. W. 1963. A new corn disease in Ohio. Plant Dis Rep. 47:1107-1108.

14. Jones, M., Boyd, E., and Redinbaugh, M. 2011. Responses of maize (Zea mays L.) near isogenic lines carrying Wsm1, Wsm2, and Wsm3 to three viruses in the Potyviridae. Theor. Appl. Genet. 123:729-740.

15. Karyeija, R. F., Kreuze, J. F., Gibson, R. W., and Valkonen, J. P. T. 2000. Synergistic interactions of a Potyvirus and a phloem-limited crinivirus in sweet potato plants. Virology 269:26-36.

16. Legg, J. P., and Fauquet, C. M. 2004. Cassava mosaic geminiviruses in Africa. Plant Mol. Biol. 56:585-599.

17. Louie, R. 1986. Effects of genotype and inoculation protocols on resistance evaluation of maize to maize-dwarf mosaic-virus strains. Phytopathology 76:769-773.

18. Louie, R. 1999. Diseases caused by viruses. Pages 49-55 in: Compendium of Corn Diseases, Third Edition. D. G. White, ed. American Phytopathological Society, St. Paul, MN

19. Louie, R., and Anderson, R. J. 1993. Evaluation of maize chlorotic dwarf virus-resistance in maize with multiple inoculations by Graminella 
nigrifrons (Homoptera, Cicadellidae). J. Econ. Entomol. 86:1579-1583.

20. Louie, R., Knoke, J. K., and Gordon, D. T. 1974. Epiphytotics of maizedwarf mosaic and maize chlorotic dwarf diseases in Ohio. Phytopathology 64:1455-1459.

21. Mcmullen, M. D., Roth, B. A., and Townsend, R. 1996. Maize chlorotic dwarf virus and resistance thereto. US patent number US5569828. U.S. Patent Office.

22. Meyer, M. D., and Pataky, J. K. 2010. Increased severity of foliar diseases of sweet corn infected with maize dwarf mosaic and sugarcane mosaic viruses. Plant Dis. 94:1093-1099.

23. Norris, D. O. 1951. Spotted wilt of potato. I. The field disease and studies of the causal virus. Aust. J. Agric. Res. 2:221-242.

24. Pruss, G., Ge, X., Shi, X. M., Carrington, J. C., and Vance, V. B. 1997. Plant viral synergism: The potyviral genome encodes a broad-range pathogenicity enhancer that transactivates replication of heterologous viruses. Plant Cell 9:859-868.

25. Rochow, W. F., and Ross, A. F. 1955. Virus multiplication in plants doubly infected by potato virus-X and virus-Y. Virology 1:10-27.

26. Roossinck, M. J. 2008. Plant Virus Evolution. Springer-Verlag, Heidelberg, Germany.

27. Rosenkranz, E. 1969. A new leafhopper-transmissible corn stunt disease agent in Ohio. Phytopathology 59:1344-1346.

28. Rozen, S., and Skaletsky, H. 2000. Primer3 on the WWW for general users and for biologist programmers. Methods Mol. Biol. 132:365-386.

29. Sanfacon, H., Wellink, J., Le Gall, O., Karasev, A., van der Vlugt, R., and Wetzel, T. 2009. Secoviridae: A proposed family of plant viruses within the order Picornavirales that combines the families Sequiviridae and Comoviridae, the unassigned genera Cheravirus and Sadwavirus, and the proposed genus Torradovirus. Arch. Virol. 154:899-907.

30. Scheets, K. 1998. Maize chlorotic mottle machlomovirus and wheat streak mosaic rymovirus concentrations increase in the synergistic disease corn le- thal necrosis. Virology 242:28-38.

31. Scott, G. E., and Rosenkranz, E. 1981. Effectiveness of resistance to maizedwarf mosaic and maize chlorotic dwarf viruses in maize. Phytopathology 71:937-941.

32. Sherwood, J. L. 1987. Mechanisms of cross-protection between plant-virus strains. In: Plant Resistance to Viruses. Ciba Foundation Symposium. Vol. 133:136-150. D. Evered and S. Harnett, eds. Wiley, New York.

33. Shukla, D. D., Frenkel, M. J., McKern, N. M., Ward, C. W., Jilka, J., Tosic, M., and Ford, R. E. 1992. Present status of the sugarcane mosaic subgroup of potyviruses. Arch. Virol. Suppl. 5:363-373.

34. Stewart, L. R. 2011. Waikaviruses: studied but not understood. APSnet feature. Online publication. http://www.apsnet.org/publications/apsnetfeatures/ Pages/waikavirus.aspx

35. Stewart, L. R., Bouchard, R., Redinbaugh, M. G., and Meulia, T. 2012. Complete sequence and development of a full-length infectious clone of an Ohio isolate of Maize dwarf mosaic virus (MDMV). Virus Res. 165:219-224.

36. Syller, J. 2012. Facilitative and antagonistic interactions between plant viruses in mixed infections. Mol. Plant Pathol. 13:204-216.

37. Todd, J. C., Ammar, E. D., Redinbaugh, M. G., Hoy, C., and Hogenhout, S. A. 2010. Plant host range and leafhopper transmission of Maize fine streak virus. Phytopathology 100:1138-1145.

38. Tu, J. C., and Ford, R. E. 1969. Effect of temperature on maize dwarf mosaic virus infection incubation and multiplication in corn. Phytopathology 59:699-702.

39. Vance, V. B. 1991. Replication of potato virus X RNA is altered in coinfections with potato virus Y. Virology 182:486-494.

40. Williams, M. M., and Pataky, J. K. 2012. Interactions between maize dwarf mosaic and weed interference on sweet corn. Field Crops Res. 128:48-54.

41. Zhang, X. S., Holt, J., and Colvin, J. 2001. Synergism between plant viruses: A mathematical analysis of the epidemiological implications. Plant Pathol. 50:732-746. 